\title{
DETERMINANTS OF THE INFLOW OF FOREIGN DIRECT INVESTMENT: EMPIRICAL EVIDENCE FROM PAKISTAN
}

\author{
Muhammad Saad"\& Iing Lukman ${ }^{\dagger}$
}

\begin{abstract}
This study aims to investigate empirically the various factors which affect the inflow of Foreign Direct Investment (FDI) in Pakistan over the period of 1980 to 2018 and used in this study are population, GDP per capita represent market size, energy consumption, inflation rate and financial development as explanatory variables. The Augmented Dickey Fuller and Philips Perron tests were used to check stationarity level of the data series; the Autoregressive Distributed Lag (ARDL) approach was employed. The empirical results show that GDP, Inflation, Energy and population growth have positive and significant effect on FDI, while the financial development have negative and significant effect on FDI. Findings of the study suggest that the government should make suitable policies to attract more FDI into Pakistan in order to improve economic growth and thereby society welfare.
\end{abstract}

Keyword: FDI; GDP per capita; population; financial development

\section{Introduction}

Foreign Direct Investment (FDI) is an investment in the economy which is done by foreigners. The aim of the foreign investors to investment in developing countries is to earn more profit and give benefit to the country, in which, they give benefit in the form of employment opportunities and influence its economic growth. But risk such as inflation risk, Horizon risk, Longevity risk, Reinvestment risk, liquidity risk and market risk etc. is always connected with the inflow of FDI. Many prior studies highlighted the

\footnotetext{
MPhil Scholar, Department of Economics, Abdul Wali Khan University Mardan, KPPakistan, Email: muhammadsaaduom@gmail.com

+ Department of Accounting, Faculty of Economics, Universtas Malahayati, Bandar Lumpung, Indonesai
} 
tremendous role plays by the global FDI inflows in the economic development, as it bring capital, managerial skill, create jobs opportunities, boost competition in local firm, increase productivity, and increase government revenues and much more (UNCTAD, 2014; Azam, 2015; Ahmad and Khan, 2018; Azam \& Gavrila, 2015; Khan et al. 2014; Gupta \& Singh, Balata et al., 2016; Khan and Khan, 2018; Azam 2019ab; Khan et al., 2019). FDI offers supply chain with the help of the local investors, economies of scale and cost benefit and the expenditure help to attract FDI. As government spending increases will lead to increases the economic growth, increase an employment and national incomes. When the economic growth of the nation raises will invite foreign investors for investment (Foster \& Magdoff, 2009).

Multinational Corporations (MNCs) wants to do investment in those places where market size is large and macroeconomic environment are stable. However, the world market size increase day by day and there is increase in the competition among host countries to pull FDI. But, when the economic fundamentals are not capable for the inflow of FDI, then, it badly affect the home country economic indicators (Dunning 1993, Globeran \& Shapiro 1999, Shapiro \& Globermsn 2001). Indeed, FDI inflow is vital for developed and less developed economies to increase and improve their economic growth. If we look some years back FDI is the largest sources of capital flow in emerging economies his contribution in security, private lends, and official assistance. The support of FDI was forty five percent of net foreign resources streams to emerging countries in 1997 as compared to sixteen percent in the year of 1986 (Perkins, 2001). FDI is reflected an important source of financial development in emerging economies. Many studies shows FDI plays significant performance in the developing process of growth in emerging economies and also in the development process of human resources, technological progress, capital formation and international trade, standard living infrastructure (UNCTAD, 2006).

According to Dunning (2002) that the inflow of FDI from emerging countries it has been observed that old-style economic variables are more important, however, FDI from more advanced developed economies is increasingly looking for corresponding knowledge, rigorous resources and skills, a helpful and clear marketable, permissible communication infrastructure and government policies satisfactory to worldwide revolution and free enterprise. This has not been empirically verified the existing studies empirically explore the distinction response of FDI from advanced and emerging nation to the home nation depends on the selective FDI policies and investment settlements.

One advantage of FDI is that it helps in providing greater capital, foreign exchange, technology and entrance to external market thereby increasing economic benefits to the home country (World Bank, 2014; Crespo \& Fontura, 2007; Romer, 1993). To developed and improve energy 
sector, telecom sectors, transformation and infrastructure, banking and finance sector, health and education sector etc. (Aizenman \& Noy, 2006). The Government of Pakistan introduced economic reform policies which were based on market in early 1980s. The management frees up its business regime by the holding of this reform in 1988 and monetary inducements to external investment by varies of tax reduction; lend facilities and tariff decrease and has improved stability in overseas exchange. The government opened agriculture sector, telecommunication sector, energy sector and insurance sector to FDI and they further liberalizes their policies in 1990. But the FDI remains small as associated with other emerging countries due to no stability in political system and policies (Khan, 1999). Paradigm (1993) states that cross-method of FDI is determine by size of the market and income level, infrastructure, stability in political and macroeconomics constancy. Nishat and Anjum (1998) concludes that FDI can be attracted by the power of politics, peaceful act and command position, level of technical labor force and mineral resources and the stable policies of the state. Breaking work dunning suggests that attraction of FDI from advanced economies depend on government strategies, obvious supremacy and compassionate organization of the country which are hosting FDI.

Rahman, (2016) stated that Pakistan is developing country and facing low foreign reserve in the past years. Since 1960 Pakistan has receiving foreign debt but due to no proper management to invest foreign debt is increasing overtime on Pakistan economy which adversely affects the development process of the nation. The government of Pakistan fails to increase the inflow of FDI due to some economical, social and political factors in past fifteen years.

The motivation of this study is based on the importance of inflow of FDI role in the process of economic growth and development of developing country Pakistan. Therefore, this study is conducted to investigate the various variables factors which determine the inflow of FDI into Pakistan.

This article is organized as follows; Section 2 present review of relevant literature. Section 3 present models of the study, data, and estimation techniques. Section 4 presents results and discussion. Finally, section 5 presents conclusions and recommendations.

\section{Literature Review}

Aqeel and Mohammed (2005) explored the main determents of FDI in Pakistan by the data period 1961-2003.The outcome of the study confirm that the tariff rate, exchange rate, tax rate, credit to private sector and per capita GDP are significantly and positively related only wage rate general price index are negatively related to FDI. The study highlights short run and the long run role of these variables in inviting FDI and its progress. Khan and Nawaz (2010) concluded that gross domestic product growth rate show 
progressive effect on inflow of FDI in Pakistan. The result confirmed that export is the chief determining factor of FDI in Pakistan. wan et al (2011) explored the determinants of FDI and their results indicated that gross domestic product, real growth rate of gross domestic product, gross fixed capital formation, foreign exchange reserve, degree of trade openness and per capita income are important and progressive influence on inflow of FDI in Pakistan. Azeem et al (2012) observed the determinants of FDI and concluded that there are negative impact on investment by partner investing and GDP and GDP growth rate, trade, total government expenses, are positive relationship and population growth has adversely connected with FDI inflow, while, Gravity has no affect on the inflow FDI.

Akram (2014) conclude that electric power consumption, total debt services, gross domestic fixed capital formation shows progressive effect on FDI while inflation has destructive effect on FDI. Latif and Latief (2019) explored the condition of power sector and energy sector of Pakistan and they investigated the causality between FDI in energy and power sectors. The results suggested that grater amount of FDI goes to power and energy sectors of Pakistan. The results also suggest short run causal relationship between economic growth and energy consumption and the results confirm long run causality of energy consumption.

Table 1: Summary of Literature Review

\begin{tabular}{|c|c|c|c|c|c|}
\hline Author & $\begin{array}{l}\text { Time } \\
\text { period }\end{array}$ & $\begin{array}{l}\text { Reg } \\
\text { ress } \\
\text { and } \\
\end{array}$ & Regressors & Model & Major finding \\
\hline $\begin{array}{l}\text { Aqeel \& } \\
\text { Nishat } \\
(2005)\end{array}$ & $\begin{array}{l}1961 \\
- \\
2003\end{array}$ & FDI & $\begin{array}{l}\text { tariff, exchange } \\
\text { rate, tax, private } \\
\text { lend zone and } \\
\text { overall price } \\
\text { catalogue }\end{array}$ & $\begin{array}{l}\text { cointegration } \\
\text { and error- } \\
\text { correlation } \\
\text { techniques }\end{array}$ & $\begin{array}{l}\text { All variables show } \\
\text { significant and } \\
\text { positive signs except } \\
\text { wage rate, general } \\
\text { price index. }\end{array}$ \\
\hline $\begin{array}{l}\text { Khan \& } \\
\text { Nawaz } \\
(2010)\end{array}$ & $\begin{array}{l}1970 \\
- \\
2005\end{array}$ & FDI & $\begin{array}{l}\text { yearly } \\
\text { progression rate, } \\
\text { exchange rate, } \\
\text { export of goods } \\
\text { and services, } \\
\text { TAR }\end{array}$ & OLS & $\begin{array}{l}\text { The impact of GDP } \\
\text { growth rate has } \\
\text { positive on FDI } \\
\text { inflow of Pakistan. } \\
\text { export is also major } \\
\text { determining factor } \\
\text { of FDI }\end{array}$ \\
\hline $\begin{array}{l}\text { Awan et } \\
\text { al. (2011) }\end{array}$ & $\begin{array}{l}1996 \\
- \\
2008\end{array}$ & FDI & $\begin{array}{l}\text { GDP, real GDP } \\
\text { growth rate, gross } \\
\text { fixed capital } \\
\text { formation, } \\
\text { foreign exchange } \\
\text { reserve, degree of } \\
\text { trade openness } \\
\text { and per capita } \\
\text { income }\end{array}$ & $\begin{array}{l}\text { Error } \\
\text { correlation } \\
\text { Model }\end{array}$ & $\begin{array}{l}\text { The results variables } \\
\text { shows significant } \\
\text { and progressive } \\
\text { encouragement on } \\
\text { inflow of FDI into } \\
\text { Pakistan }\end{array}$ \\
\hline
\end{tabular}




\begin{tabular}{|c|c|c|c|c|c|}
\hline $\begin{array}{l}\text { Azeem et } \\
\text { al. (2012) }\end{array}$ & $\begin{array}{l}1999 \\
- \\
2009\end{array}$ & FDI & $\begin{array}{l}\text { GDP, GDP per } \\
\text { capita, GDP } \\
\text { growth rate, } \\
\text { inflation rate, } \\
\text { population growth } \\
\text { rate, population } \\
\text { growth rate and } \\
\text { distance }\end{array}$ & $\begin{array}{l}\text { two test fixed } \\
\text { and random } \\
\text { effect }\end{array}$ & $\begin{array}{l}\text { All variables are } \\
\text { progressive with } \\
\text { FDI but population } \\
\text { growth is } \\
\text { destructively } \\
\text { associated with FDI }\end{array}$ \\
\hline $\begin{array}{l}\text { Danish \& } \\
\text { Akram } \\
(2014)\end{array}$ & $\begin{array}{l}1990 \\
\text { to } \\
2010\end{array}$ & FDI & $\begin{array}{l}\text { Debt services, } \\
\text { electric } \\
\text { consumption, } \\
\text { total exterior } \\
\text { lends, gross fixed } \\
\text { capital formation } \\
\text { and inflation. }\end{array}$ & OLS & $\begin{array}{l}\text { Electric power } \\
\text { consumption, total } \\
\text { debt services, } \\
\text { domestic fixed } \\
\text { capital formation } \\
\text { have progressive } \\
\text { effect on FDI while } \\
\text { inflation has adverse } \\
\text { effect on FDI }\end{array}$ \\
\hline $\begin{array}{l}\text { Masoof } \\
\text { (2015) }\end{array}$ & $\begin{array}{l}1990 \\
\text { to } \\
2014\end{array}$ & FDI & $\begin{array}{l}\text { GDP, Gross } \\
\text { capital formation, } \\
\text { inflation and } \\
\text { incidental taxes. }\end{array}$ & $\begin{array}{l}\text { Regression } \\
\text { model }\end{array}$ & $\begin{array}{l}\text { They suggest that } \\
\text { taxes are increasing } \\
\text { day by day, inflation } \\
\text { rate is high and GDP } \\
\text { growth rate is lower } \\
\text { causes low FDI in } \\
\text { Pakistan. }\end{array}$ \\
\hline $\begin{array}{l}\text { Rehman } \\
\text { (2016) }\end{array}$ & $\begin{array}{l}1984 \\
\text { to } \\
2015\end{array}$ & FDI & $\begin{array}{l}\text { market size, } \\
\text { openness, } \\
\text { inflation and } \\
\text { natural resource }\end{array}$ & $\begin{array}{l}\text { co-integration } \\
\text { and error } \\
\text { correction } \\
\text { techniques }\end{array}$ & $\begin{array}{l}\text { Economic and social } \\
\text { have long run } \\
\text { determinants on } \\
\text { inflow of FDI and } \\
\text { vector error } \\
\text { correlation also } \\
\text { confirms that short } \\
\text { run relation exists. }\end{array}$ \\
\hline $\begin{array}{l}\text { Khalid \& } \\
\text { Chaudhry } \\
\text { (2017) }\end{array}$ & $\begin{array}{l}1980 \\
\text { to } \\
2015\end{array}$ & FDI & $\begin{array}{l}\text { GDP per capita, } \\
\text { gross national } \\
\text { income per } \\
\text { capita, exchange } \\
\text { rate, trade } \\
\text { openness, dummy } \\
\text { for dictatorship }\end{array}$ & ARDL model & $\begin{array}{l}\text { GDP per capita, GNI, } \\
\text { and trade openness } \\
\text { shows positive } \\
\text { impact on FDI while } \\
\text { the impression of } \\
\text { exchange rate is } \\
\text { negative. Dictatorship } \\
\text { results shows } \\
\text { progressive result on } \\
\text { inflows of FDI }\end{array}$ \\
\hline $\begin{array}{l}\text { Latif \& } \\
\text { Iatief } \\
(2019)\end{array}$ & $\begin{array}{l}1990 \\
\text { to } \\
2017\end{array}$ & FDI & $\begin{array}{l}\text { economic growth } \\
\text { and power and } \\
\text { energy sector }\end{array}$ & $\begin{array}{l}\text { Johansen co- } \\
\text { integration } \\
\text { and granger } \\
\text { causality tests }\end{array}$ & $\begin{array}{l}\text { results confirm short } \\
\text { run causal } \\
\text { connection between } \\
\text { economic } \\
\text { development and } \\
\text { energy depletion and } \\
\text { also results suggest } \\
\text { long run causality of } \\
\text { energy use }\end{array}$ \\
\hline
\end{tabular}




\section{Methodology of the Study}

This study used five independent variables which are the important determining factors of FDI and annual time series data for the year 1980 to 2018. This study used descriptive statistics, correlation, ADF and PP test to check stationarity and ARDL and ARDL bound test are estimate the model and other diagnostic test.

\section{Model Specification}

This study used FDI as dependent and population, GDP, Energy, inflation and financial development as independent variables. The same model was used by Azeem et al. (2012), Haseeb et al. (2014), Muhammad et al. (2015). Khalid and Chaudhary (2017) and Azam et al. (2019).

\section{In linear form}

$$
\text { FDI }_{\mathrm{t}}=\beta_{0}+\beta_{1} \text { POP }_{\mathrm{t}}+\beta_{2} \text { GDP }_{\mathrm{t}}+\beta_{3} \mathrm{ENG}_{\mathrm{t}}+\beta_{4} \mathrm{FD}_{\mathrm{t}}+\beta_{5} \mathrm{INF}_{\mathrm{t}}+\mu_{\mathrm{t}}
$$

\section{In ARDL Form}

$$
\begin{aligned}
\text { FDI }_{\mathrm{t}}=\boldsymbol{\beta}_{0}+ & +\sum_{\mathrm{i}=1}^{\mathrm{n}_{1}} \boldsymbol{\beta}_{1 \mathrm{i}} \mathrm{FDI}_{\mathrm{t}-\mathrm{i}}+\sum_{\mathrm{i}=1}^{\mathrm{n}_{2}} \boldsymbol{\beta}_{2 \mathrm{i}} \mathbf{P O P}_{\mathrm{t}-\mathrm{i}}+\sum_{\mathrm{i}=1}^{\mathrm{n}_{3}} \boldsymbol{\beta}_{3 \mathrm{i}} \mathbf{G D P}_{\mathrm{t}-\mathrm{i}}+\sum_{\mathrm{i}=1}^{\mathrm{n}_{4}} \boldsymbol{\beta}_{4 \mathrm{i}} \mathbf{E N G}_{\mathrm{t}-\mathrm{i}}+\sum_{\mathrm{i}=1}^{\mathrm{n}_{5}} \boldsymbol{\beta}_{5 \mathrm{i}} \mathbf{F D}_{\mathrm{t}-\mathrm{i}} \\
& +\sum_{\mathrm{i}=1}^{\boldsymbol{\beta}_{6 \mathrm{i}} \mathrm{INF}_{\mathrm{t}-\mathrm{i}}+\boldsymbol{\mu}_{\mathrm{t}}}
\end{aligned}
$$

Table 2: Variables and Data Source

\begin{tabular}{lll}
\hline Variables & Description and source & Symbols \\
\hline $\begin{array}{l}\text { Foreign Direct } \\
\text { Investment }\end{array}$ & FDI, net inflows (\% of GDP) data is from WDI. & FDI \\
$\begin{array}{l}\text { GDP per capita } \\
\text { Population }\end{array}$ & $\begin{array}{l}\text { GDP per capita (current US dollar) data is from WDI. } \\
\text { Urban population growth (annual \%) data is from WDI }\end{array}$ & GDP \\
Energy & $\begin{array}{l}\text { Energy use (kilo of oil equivalent per capita) data is } \\
\text { from WDI }\end{array}$ & ENG \\
$\begin{array}{l}\text { Inflation } \\
\begin{array}{l}\text { Financial } \\
\text { development }\end{array}\end{array}$ & $\begin{array}{l}\text { M2 }(\% \text { of GDP) is used as proxy for financial } \\
\text { development data is from WDI. }\end{array}$ & INF \\
\hline
\end{tabular}


Table 3: Descriptive Analyses

\begin{tabular}{|c|c|c|c|c|c|c|}
\hline & FDI & FD & GDP & INF & LENG & POP \\
\hline Mean & 0.699579 & 49.21790 & 843.4319 & 9.079500 & 6.113689 & 4.133053 \\
\hline Median & 0.612998 & 48.20324 & 649.8048 & 7.879657 & 6.136581 & 4.091244 \\
\hline Maxi & 2.010007 & 61.54371 & 1547.853 & 19.89115 & 6.261040 & 5.367890 \\
\hline Minimum & 0.063242 & 38.59470 & 334.8476 & 0.400237 & 5.857626 & 3.575547 \\
\hline Std. De & 0.483321 & 6.838261 & 444.9449 & 4.955728 & 0.103486 & 0.445999 \\
\hline Skewness & 0.687800 & 0.136509 & 0.344 & 0.724931 & -0.892680 & 0.768855 \\
\hline Kurt & 2.790380 & 1.917882 & 1.429269 & 2.871294 & 2.926384 & 3.380203 \\
\hline Jarqu & 3.146350 & 2.023966 & 4.782348 & 3.442831 & 5.18 & 4.077300 \\
\hline Probab & 0.207386 & 0.363498 & 0.091522 & 0.178813 & 0.074701 & 0.130204 \\
\hline Sum & 27.28360 & 1919.498 & 32893.84 & 354.1005 & 238.4339 & 161.1891 \\
\hline $\begin{array}{l}\text { Sum Sq. } \\
\text { Dev. }\end{array}$ & 8.87 & 1776.949 & 7523087. & 933 & 0.406952 & 7.558761 \\
\hline Observations & 39 & 39 & 39 & 39 & 39 & 39 \\
\hline
\end{tabular}

Table 4: Correlations Matrix

\begin{tabular}{lcccccc}
\hline & FDI & FD & GDP & INF & LENERGY & POP \\
\hline FDI & 1.000000 & 0.402846 & 0.628013 & 0.255056 & 0.345582 & 0.633437 \\
FD & 0.402846 & 1.000000 & 0.864932 & -0.046610 & 0.658251 & 0.817784 \\
GDP & 0.628013 & 0.864932 & 1.000000 & -0.023709 & 0.623209 & 0.912916 \\
INF & 0.255056 & -0.046610 & -0.023709 & 1.000000 & 0.267953 & 0.034037 \\
LENG & 0.345582 & 0.658251 & 0.623209 & 0.267953 & 1.000000 & 0.694080 \\
POP & 0.633437 & 0.817784 & 0.912916 & 0.034037 & 0.694080 & 1.000000 \\
\hline
\end{tabular}

Table 5: Unit Root Tests

\begin{tabular}{|c|c|c|c|c|c|}
\hline \multirow[t]{2}{*}{ Variables } & \multicolumn{2}{|c|}{$\begin{array}{c}\text { ADF test Values } \\
\text { (p-value) }\end{array}$} & \multicolumn{2}{|c|}{$\begin{array}{c}\text { PP test Values } \\
\text { (p-value) }\end{array}$} & \multirow[b]{2}{*}{ Decision } \\
\hline & At level & $\begin{array}{c}\text { At } 1^{\text {st }} \\
\text { Difference }\end{array}$ & At level & $\begin{array}{c}\text { At } 1^{\text {st }} \\
\text { Difference }\end{array}$ & \\
\hline FDI & $\begin{array}{l}-4.041 \\
(0.003)\end{array}$ & & $\begin{array}{c}-4.241 \\
(0.0019)\end{array}$ & & $\begin{array}{c}\text { Stationary at } \\
\text { level }\end{array}$ \\
\hline GDP & $\begin{array}{l}-0.065 \\
(0.946)\end{array}$ & $\begin{array}{l}-5.455 \\
(0.0001)\end{array}$ & $\begin{array}{l}-0.118 \\
(0.940)\end{array}$ & $\begin{array}{c}-5.47 \\
(0.000)\end{array}$ & $\begin{array}{l}\text { Stationary At } \\
1^{\text {st }} \text { Difference }\end{array}$ \\
\hline POP & $\begin{array}{c}1.610 \\
(0.999)\end{array}$ & $\begin{array}{l}-5.415 \\
(0.000)\end{array}$ & $\begin{array}{c}1.728 \\
(0.999)\end{array}$ & $\begin{array}{l}-5.415 \\
(0.0001)\end{array}$ & $\begin{array}{l}\text { Stationary At } \\
1^{\text {st }} \text { Difference }\end{array}$ \\
\hline INF & $\begin{array}{l}-5.052 \\
(0.000)\end{array}$ & & $\begin{array}{c}-5.06 \\
(0.0002)\end{array}$ & & $\begin{array}{c}\text { Stationary at } \\
\text { level }\end{array}$ \\
\hline FD & $\begin{array}{l}-1.346 \\
(0.597)\end{array}$ & $\begin{array}{l}-6.72 \\
(0.000)\end{array}$ & $\begin{array}{c}-1.21 \\
(0.659)\end{array}$ & $\begin{array}{l}-6.925 \\
(0.000)\end{array}$ & $\begin{array}{l}\text { Stationary At } \\
1^{\text {st }} \text { Difference }\end{array}$ \\
\hline ENERGY & $\begin{array}{l}-2.444 \\
(0.136)\end{array}$ & $\begin{array}{l}-5.874 \\
(0.000)\end{array}$ & $\begin{array}{c}-2.60 \\
(0.099)\end{array}$ & $\begin{array}{c}-5.87 \\
(0.000)\end{array}$ & $\begin{array}{l}\text { Stationary At } \\
1^{\text {st }} \text { Difference }\end{array}$ \\
\hline
\end{tabular}


The unite root tests result shows that FDI and inflation are stationary at level and GDP, population, Financial development and energy are stationary at first difference, therefore, these results recommend ARDL model.

Table 6: ARDL MODEL Results

\begin{tabular}{ccccc}
\hline Variables & Coefficient & Std. Error & t-Statistic & Prob.* $^{*}$ \\
\hline FDI(-1) & -0.172454 & 0.167090 & -1.032104 & 0.3103 \\
FD & -0.032001 & 0.017220 & -1.858397 & 0.0729 \\
GDP & 0.000793 & 0.000358 & 2.217431 & 0.0343 \\
INF & 0.026990 & 0.012115 & 2.227754 & 0.0335 \\
INF(-1) & 0.019784 & 0.014090 & 1.404117 & 0.1706 \\
LENERGY & 1.944091 & 1.011330 & 1.922311 & 0.0641 \\
POP & 0.769191 & 0.358929 & 2.143018 & 0.0403 \\
C & 10.01507 & 5.366171 & 1.866335 & 0.0718 \\
R-squared & 0.604083 & Adjusted R-squared & 0.511703 \\
F-statistic (P-value) & \multicolumn{5}{c}{$6.539079(0.0001)$} \\
\hline
\end{tabular}

The ARDL results shows that GDP, Inflation, Energy and population growth have positive and significant effect on FDI, while the financial development have negative and significant effect on FDI. Awan et al. (2011) and Masoof (2015) was found that GDP has positive and significant effect on FDI. Rehman (2016) was also confirmed that inflation has significant effect on FDI. Latif \& Iatief (2019) confirmed that economic growth and power and energy have significant and positive effect on economic growth. The R-squared value is 0.60 , which means that $60 \%$ variation in the FDI due these variables.

\section{Table 7: ARDL Bound Test Results}

\begin{tabular}{lcc}
\hline \multicolumn{2}{l}{ Null Hypothesis: No long-run relationships exist } & \\
\hline Test Statistic & Value & $\mathrm{k}$ \\
F-statistic & 5.206467 & 5 \\
Critical Value Bounds & & \\
Significance level & I0 Bound & I1 Bound \\
$10 \%$ level of significance & 2.26 & 3.35 \\
$5 \%$ level of significance & 2.62 & 3.79 \\
$2.5 \%$ level of significance & 2.96 & 4.18 \\
$1 \%$ level of significance & 3.41 & 4.68 \\
\hline
\end{tabular}


The ARDL bound test results shows that there exists the long run relationship among these variables because the calculated value of bound test is greater than upper bound value, therefore, this study reject the null hypothesis that there existed no relationship in the long run.

Table 8: Diagenetic Tests Results

\begin{tabular}{lclc}
\hline Test Name & $\begin{array}{c}\text { Test Statistics } \\
\text { value } \\
\text { (p-value) }\end{array}$ & Null Hypothesis $\left(\mathbf{H}_{\mathbf{0}}\right)$ & Decision \\
\hline Jarque-bera & $\begin{array}{c}1.4137 \\
(0.4932)\end{array}$ & $\begin{array}{l}\text { The residual are normally } \\
\text { distributed. }\end{array}$ & $\begin{array}{c}\text { Can't Reject } \\
\mathrm{H}_{0}\end{array}$ \\
$\begin{array}{l}\text { Breusch-Godfrey } \\
\text { Serial Correlation }\end{array}$ & 0.8426 & $\begin{array}{l}\text { There are no serial correlations } \\
\text { LM Test }\end{array}$ & $\begin{array}{c}\text { Can't Reject } \\
\mathrm{H}_{0}\end{array}$ \\
$\begin{array}{l}\text { Breusch-Pagan- } \\
\text { Godfrey test }\end{array}$ & $0.4412)$ & in the data. & Can't Reject \\
$\begin{array}{l}\text { Ramsey RESET } \\
\text { Test }\end{array}$ & $0.6484)$ & $\begin{array}{l}\text { There are Homoskedasticity in } \\
\text { the data. }\end{array}$ & $\begin{array}{c}\mathrm{H}_{0} \\
\text { Can't Reject } \\
\mathrm{H}_{0}\end{array}$ \\
\hline
\end{tabular}

\section{Conclusion and Recommendation}

FDI play a vital role of economic growth of a country, therefore, this study was conducted with the main aim is to investigate the major determinant of FDI in Pakistan for the year of 1980 to 2018. Main objective of the study is to catch varies variables, which have significant effects on FDI in Pakistan. For this purpose the study tests the effect of population, GDP per capita, energy, financial development and inflation on FDI. GDP, Inflation, Energy and population growth have positive and significant effect on FDI, while the financial development have negative and significant effect on FDI. Therefore, this study concludes that GDP, Inflation, Energy, population growth and financial development are the major determinants of FDI in Pakistan.

FDI is a best opportunity of emerging nations to increase its economic growth. Though, Pakistan is developing country thus Pakistan needs to invite FDI in order to raise its economic growth. The results of this study providing the way to policy maker to pull FDI in Pakistan. The administration must implement suitable and correct procedures to raise FDI in Pakistan. The government must support local investors to start investing in Pakistan it will also help in inviting external investors to come for investing in Pakistan. The country must possess political stability and improve act and command position in the nation in order to attract external investors in the home nation. 


\section{References}

Ahmad, A., \& Khan, F., (2018). Investigating the determinants of youth unemployment in Pakistan. Pakistan Journal of Humanities \& Social Science Research, 1(1), 1-12

Akhtar, M.H. (2000). The determinants of Foreign direct investment in Pakistan: the Lahore Journal of Economics, 5(1), 01-22

Alshamsi, K.H. Hussin, R.M., and Azam, M. (2015). The impact of inflation and GDP per capita on foreign direct investment: the case of United Arab Emirates. Investment Management and Financial Innovations, 12(3): 132-141.

Akram, A. \& Danish. Q.R. (2014). Empirical determinants of foreign direct investment in Pakistan: Journal of Business \& Economics, 2(2), 61-70.

Ang, J.,B. (2008). Determinants of foreign direct investment in Malaysia: Journal of Policy Modeling, 30(1), 185-189

Awan, Z.,M. Khan, B. \& Zaman, U., K. (2011). Economic determinants of foreign direct investment in commodity producing sector in Pakistan: African Journal of Business Management, 5(2) 537-545.

Awan, G,A. Ahmad, W. Shahid, P. \&Hassan, J. (2014). Factors affecting foreign direct investment in Pakistan: International Journal of Business and Management Review, 2(4), 21-35.

Audi, M. (2011).Is foreign direct investment a cure economic growth in developing countries: Journal of International Business and Economics, 11(4), 32-51.

Azeem, W.S. Hussain, H. \& Hussain, Y,R. (2012). The determinants of foreign direct investment in Pakistan: Scientific Journal of Logistic, 8(2), 81-97.

Azam, M. (2010). Economic determinants of foreign direct investment in Armenia, Kyrgyz Republic and Turkmenistan: Eurasian Journal of Business and Economic,3(6), 27-40.

Azam, M. \& Khattak, N. (2009). Social and political factors effect on foreign direct investment in Pakistan: Gomal University Journal of Research, 25(1), 46-50.

Azam, M., (2015). The role of migrant workers remittances in fostering economic growth: The four Asian developing country's experiences. International Journal of Social Economics, 42(8):1-18.

Azam, M., and Gavrila, L. (2015). Inward foreign capital flows and economic growth in African countries. Journal of Applied Economic Sciences, X-3 (33): 362-371.

Azam M, (2019). Inequality and economic growth in Asia and the Pacific region. African and Asian Studies, 18 (2019) 288-314. doi:10.1163/15692108-12341429. 
Azam, M. (2019). Energy and economic growth in developing Asian economies. Journal of the Asia Pacific Economy DOI: 10.1080/13547860.2019.1665328.

Azam, M. and Ahmad, M.A., (2015). Role of human capital and foreign direct investment in promoting economic growth: Evidence from Commonwealth of Independent States. International Journal of Social Economics, 42(2), 89-111.

Azam, M., Nawaz, A., \& Riaz, M., (2019). Does corruption and terrorism affect foreign direct investment inflows into Pakistan? Journal of Managerial Sciences, 13(3), 85-97.

Azam, M. (2016). Does governance and foreign capital inflows affect economic development in OIC countries? Journal of Economic Cooperation and Development, 37(4) 21-50.

Bahattab, A.S., Azam, M., Gavrila, L., and Emiruallah, C., (2016). Foreign capital inflows, institutional factors and economic growth: Evidences from Republic of Yemen. Journal of Applied Economic Sciences, 5(43), 811-816.

Borensztein, E.De, G, J. Lee, J,W. (1998). How Does Foreign Direct Investment Affect Economic Growth? Journal of International Economics, 45(1), 115-135.

Behname, M. (2012). Foreign direct investment and economic growth: evidence from south Asia: Atlantic Review of Review of Economics, 2(16), 1-14.

Behrman, J. (1972). The role of international companies in Latin America Integration: The international Executive, 14(3), 18-20.

Danish, Q,R. \& Akram, A. (2014). Determinants of foreign direct investment in Pakistan: Journal of International Business and Economics, 2(2), 61-70.

Dickey, D,A. \& Fuller, A,W. (1979). Distribution of estimators for autoregressive time series with unit root: Journal of the American Statistical Association, 74(386), 427-431.

Dunning, J,H. (2002). Determinants of foreign direct investment: Globalization Induced Changes and the Role of FDI policies. Paper presented at the Annual Bank Conference on Development Economic in Europe, Oslo, mimeo.

Faras, R. \& Ghali, K.(2009). Foreign direct investment and economic growth: International Research Journal of Economic, 29(1), 134-145.

Foster, J,B \& Magdoff, F. (2009). The great financial crisis: Causes and consequences. NYU Press.

Haseeb, M., N.H. Hartani, N.A.A. Bakar, Azam M. and S. Hassan, (2014). Exports, foreign direct investment and economic growth: Empirical evidence from Malaysia (1971-2013). American Journal of Applied Sciences, 11: 1010-1015. 
Irwan S., Haseeb, M., Azam M. and Islam, R., (2015). Foreign direct investment, financial development, international trade and energy consumption: Panel data evidence from selected ASEAN countries. International Journal of Energy Economics and Policy 5(3), 841-850.

Gupta, P. \& Singh, A., (2016). Determinants of foreign direct investment inflows in BRICS Nations: A Panel Data Analysis. Emerging Economy Studies, 2(2) 1-18.

Globerman \& Shapiro. (1999) \& Shapiro \& Globerman. (2001). The determinants of international prediction: Oxford Economic Papers, 25:3.

Haq, A.(2013). Determinants of foreign direct investment in Pakistan: International Journal of Humanities and Management Science, 1(4), 264-268.

Haider, M. \& Gull, S. Afridi, A, S. Battol, S. (2017). Factor affecting foreign direct investment in Pakistan: International Journal of Business and Management, 12(2), 2410-539.

Khan, M.A, \& Khan, S. (2018). Inflation and the economic growth: evidence from Five Asian Countries. Pakistan Journal of Applied Economics, 28(2), 235-252.

Khan, A,E,R. \& Nawaz, A,M. (2010). The determinants of foreign direct investment in Pakistan: Journal of Economics, 1(2), 99-104.

Khan, F., Yasmeen, G, Sofian MUF, \& Javid, M.U., (2019). Exploring the effect of terrorism on education sector: a case study of Khyber Pakhtunkhwa-Pakistan. City University Research Journal 9(2), 340-349

Khan, F., Javeria U., \& Numan, M. (2014). Education, foreign direct investment and socio-economic development-A review. Abasyn Journal of Social Sciences, 7 (2), 269-277.

Khalid, A. \& Chaudhry, A,S. (2017). Factor affecting foreign direct investment in Pakistan: International Journal of Scientific \& Engineering Research, 8(10), 2229-5518.

Latief, R. \& Lefen, L. (2019). Foreign direct investment in the power and Energy sector, Energy Consumption and Economic Growth: Sustainability, 11(192), 1-22.

Masoof, N.(2015). Determinants and causes of low foreign direct investment in Pakistan: international journal of scientific \& research, 6(12), 2229. 5518.

Muhammad, A., Khan, S., Zainal, Z., Karuppiah, N., \& Khan, F., (2015). The impact of foreign direct investment on human capital in developing countries. Investment Management and Financial Innovations, 12(3): 155-162.

Nishat, M. \& Aqeel, A. (2005). The empirical determinants of foreign direct investment in Pakistan: Saving \& Development, 24(4), 651-664.

Nasreen, S. Fazal U. Piezada, S,S. Khanam, F. Triq, S. (2014).impact of foreign direct investment on economic growth of Pakistan: Journal of Economic and Sustainable Development, 5(11), 1700-2222. 
Phillips, P,CB. \& Perron, P,P. (1988). Testing for a unit root in the time series regression: Biometrika, 75, 335-46.

Pesaran, M,H. Shin, Y. \& Smith, RJ. (2001). Bound testing approaches to the analysis of level relationship: Journal of Applied Economics, 16(3), 289-326.

Perkins (2001) Dwight. Eonomics of development, W.W.Norton \& Company, New York.

Rihab, A,B. \& Lotfi, J,B. (2011). The institutional and cultural determinants of foreign direct investment in transaction countries: Journal of Research in International Business and Management, 1(2), 171-182.

Rehman, A. Tariq, M. \& Ahmed, S. (2015). Foreign direct investment and export performance of Pakistan: Journal of Business Studies, 11(1), 1-11.

Rehman, U,H. (2016). Comparative analysis of socio economic determinants of foreign direct investment in Pakistan: Pakistan Economics and Social Review, 2(54), 255-274.

Shah, Z. \& Ahmad, M,Q. (2003). The determinants of foreign direct investment in Pakistan: The Pakistan Development Review, 42(4), 697714.

Shah, S.W. A., Bakar, N.A., and Azam, M., (2016). Foreign direct investment, economic growth and terrorism events in Pakistan: a cointegration analysis. International Journal of Academic Research in Economics and Management Sciences, 5(4), 155-167

United Nations Conference on Trade and Development (UNCTAD). (2014). World Investment Report. UN, New York and Geneva.

World Development Indicators (2018) World Bank

Younas, S, H. Sohail, A, \& Azeem, M. (2014). Impact of foreign direct investment on economic growth of Pakistan: World Journal of Economic and Finance, 1(1), 002-005.

Yousaf, M, M. Hussain, Z. \& Ahmad, Z. (2008). Economic evaluation of foreign direct investment in Pakistan: Pakistan Economic and Social Review, 46(1), 37-56. 